\title{
Discrete and Infinite Cyclic Dimer M(II) Complexes (M = Co, Zn) Based on Angular Dipyridyl Ligands Incorporating an Amide Spacer
}

\author{
Yong Woon Shin, Tae Ho Kim, Kang Yeol Lee, Ki-Min Park, ${ }^{\dagger}$ \\ Sang Woo Han, Shim Sung Lee, Jae Sang Kim, and Jineun Kim*
}

\author{
Department of Chemistry and Research Institute of Natural Sciences, Gyeongsang National University, Chinju 660-701, Korea \\ *E-mail: jekim@gsnu.ac.kr \\ ${ }^{\dagger}$ Research Institute of Natural Sciences, Gyeongsang National University, Chinju 660-701, Korea \\ Received November 24, 2004
}

Key Words : Crystal structure, Looped coordination polymer, Co(II), Zn(II), Hydrogen bonding

An increasing interest has been directed toward the synthesis of new inorganic/organic hybrid compounds which involve the self-assembly of structural motifs into welldefined supramolecules via hydrogen bonds, metal-ligand coordination bonds, and donor-acceptor interactions. In particular, the formation of cyclic nanostructures with large cavity makes these materials potential candidates not only for the catalysis ${ }^{1}$ and selective sorption ${ }^{2}$ but also for ion exchange, ${ }^{3}$ the nonlinear optics ${ }^{4}$ and magnetism. ${ }^{5}$ In our efforts to investigate the control of the self-assembly of an organic/inorganic motifs, dipyridyl-based ligands ${ }^{6-9}$ separated by a phenyl amide spacer have attracted our attention in connection with the coordination affinity and structural control of discrete or divergent coordination networks upon metal complexation under appropriate conditions. ${ }^{10-15}$ The amide spacer is introduced to form hydrogen bonds ${ }^{16}$ which play a crucial role in fundamental biological processes, such as the expression and transfer of genetic information, and are very important for molecular recognition between receptors and substrates as well as construction of complicated supramolecular arrays through self-organization of molecules in the fields of supramolecular chemistry. ${ }^{17,18}$ Based on these considerations, we have employed angular dipyridyl ligands, $\quad N, N^{\prime}$-bis(4-pyridylcarbonyl)-4,4'-diaminodiphenyl ether $\left(\mathbf{L}^{\mathbf{1}}\right)$ and $N, N^{\prime}$-bis(4-pyridylcarbonyl)-2,6-diaminopyridine $\left(\mathbf{L}^{2}\right)$. Recently, the structure of $\mathrm{M}_{2} \mathbf{L}_{2}{ }_{2}$-type $(\mathrm{M}=\mathrm{Zn}$ and $\mathrm{Cd}$ ) molecular squares was reported by Li et al. ${ }^{19}$ Also, we have reported an interpenetrating Co(II) coordination<smiles>O=C(Nc1ccc(Oc2ccc(NC(=O)c3ccncc3)cc2)cc1)c1ccncc1</smiles>

$\mathbf{L}^{1}$<smiles>O=C(Nc1cccc(NC(=O)c2ccncc2)n1)c1ccncc1</smiles>

polymer with nano channels. ${ }^{20}$ As a result of continuing interest, we have further carried out the assembly of MOFs based on $\mathbf{L}^{1}$ and $\mathbf{L}^{2}$, and found that its chemistry is not parallel to those of previously known. ${ }^{19,20}$ Herein, we report the synthesis and crystal structures of $\left[\mathrm{CoL}^{\mathbf{1}}\left(\mathrm{NO}_{3}\right)\left(\mathrm{H}_{2} \mathrm{O}\right)_{2}-\right.$ $\left.\left(\mathrm{CH}_{3} \mathrm{OH}\right)\right]_{2} \cdot 2 \mathrm{NO}_{3} \cdot \mathrm{CH}_{3} \mathrm{CH}_{2} \mathrm{OCH}_{2} \mathrm{CH}_{3}(\mathbf{1}),\left\{\left[\mathrm{CoL}_{2}{ }_{2}\left(\mathrm{H}_{2} \mathrm{O}\right)_{2}\right]\right.$. $\left.2 \mathrm{PF}_{6} \cdot \mathrm{H}_{2} \mathrm{O}\right\}_{\mathrm{n}}(\mathbf{2})$, and $\left\{\left[\mathrm{ZnL}^{2}{ }_{2}\left(\mathrm{H}_{2} \mathrm{O}\right)_{2}\right] \cdot 2 \mathrm{NO}_{3} \cdot 12 \mathrm{H}_{2} \mathrm{O}\right\}_{\mathrm{n}}$ (3), which form a discrete cyclic dimer (1), and infinite looped coordination polymers ( $\mathbf{2}$ and $\mathbf{3}$ ), respectively.

The crystal structure of $\mathbf{1}$ is shown in Figure 1. The crystallographic analysis reveals that $\mathbf{1}$ exists as a discrete macrocyclic structure with remarkably large cavity, which includes a disordered diethyl ether molecule per two cobalt atoms. The cavity size is measured by the $\mathrm{Co}{ }^{\cdots}$ Co distance

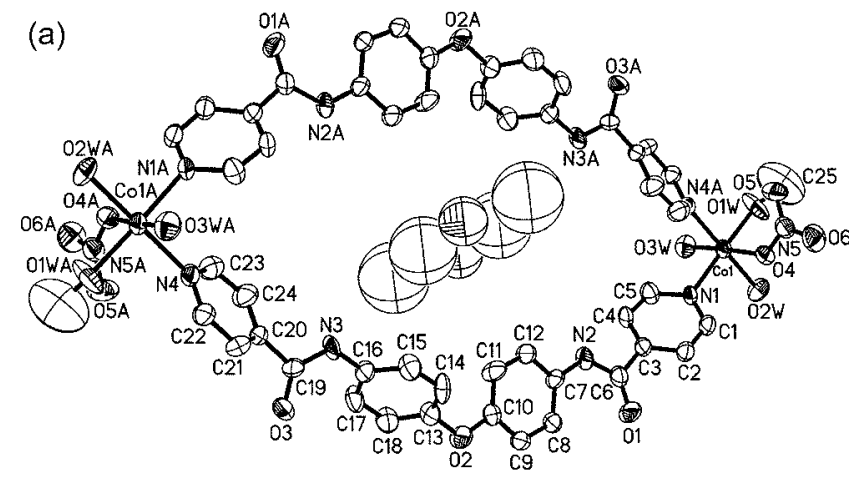

(b)

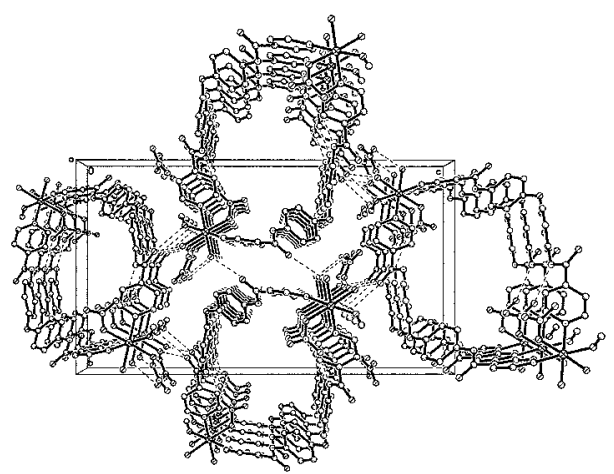

Figure 1. (a) ORTEP drawing of 1 with numbering scheme. Hydrogen atoms are omitted for clarity. (b) A view of the channels down the $a$-axis. Guest molecules are omitted for clarity. 
$(22.109 \AA)$ and the distance between two phenyl oxygen atoms $(12.242 \AA)$. The cobalt atoms are linked by two ligands through $\mathrm{Co}-\mathrm{N}$ bond to form a cyclic dimer. Cobalt center is based on a distorted octahedral environment with two pyridine nitrogen donors, one nitrate oxygen donor, two water and one methanol molecules, in which each ligand occupies the cis position. The nitrate anion ligates to the cobalt atom as a monodentate fashion. $\mathrm{O} 1 \mathrm{~W}, \mathrm{O} 3 \mathrm{~W}, \mathrm{O} 4$ and $\mathrm{N} 1$ atoms define an equatorial plane (mean deviation 0.007 $\AA$ ). The axial coordination sites are occupied by N4A and O2W [N4A-Co-O2W, 179.7(3)]. The cyclic units, $\left[\mathrm{Co}_{2} \mathbf{L}^{\mathbf{1}_{2-}}\right.$ $\left.\left(\mathrm{NO}_{3}\right)_{2}\left(\mathrm{H}_{2} \mathrm{O}\right)_{4}\left(\mathrm{CH}_{3} \mathrm{OH}\right)_{2}\right]^{+}$are linked by hydrogen bonds between nitrate ions in coordinating and non-coordinating forms and coordinating water molecules. The average distance between two cyclic units is $4.50 \AA$. Again, the cyclic units are involved intermolecular hydrogen bonds between carbonyl groups and coordinating water or methanol on adjacent cycles. As a result, these two types of intermolecular $\mathrm{H}$-bonds lead the close packed structure in such a way that each infinite channel forms the columns parallel to the crystallographic $a$-axis as shown in Figure $1 \mathrm{~b}$.

The crystal structure of $\mathbf{2}$ in Figure 2 exhibits onedimensional framework, in which two adjacent $\mathrm{Co}$ (II) ions are bridged by two $\mathbf{L}^{\mathbf{1}}$ units, forming a looped chain extending along the crystallographic $a$-axis. Each $\mathrm{Co}$ (II) ion is coordinated by four pyridyl nitrogen atoms of four different $\mathbf{L}^{1}$ units in an equatorial plane, as well as two water molecules in trans-geometry. It is interesting to compare this structure with that of $\mathbf{1}$, in which the structure is terminated by anion and solvent coordination. In case of $\mathbf{2}$, however, the use of non-coordinating $\mathrm{PF}_{6}{ }^{-}$induces the coordination of

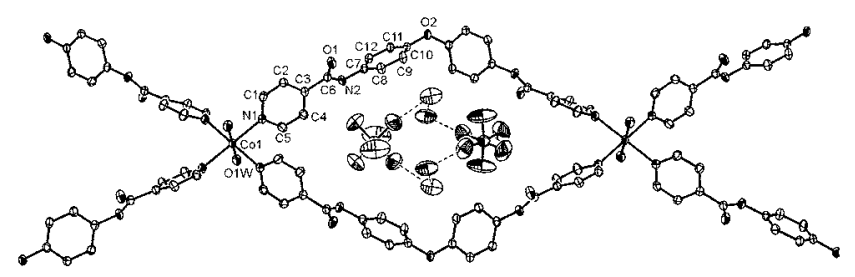

(a)

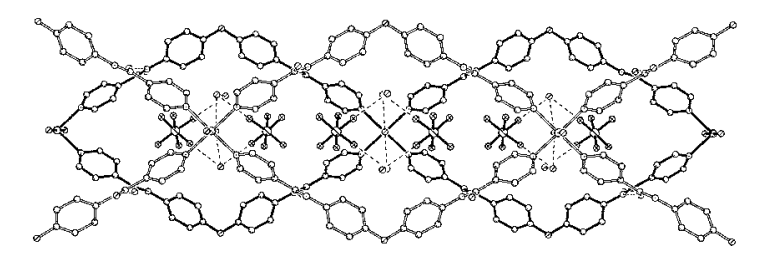

(b)

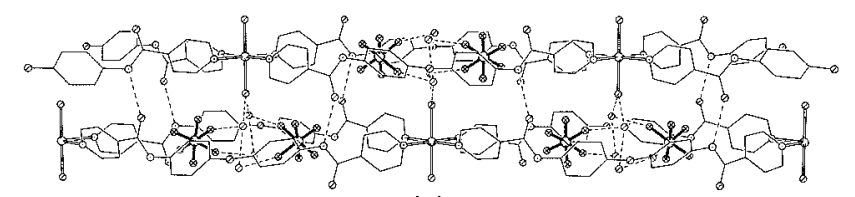

(c)

Figure 2. (a) ORTEP drawing of $\mathbf{2}$ with numbering scheme. Hydrogen atoms are omitted for clarity. (b) A view of two looped chains (A and B) of $\mathbf{2}$ down the $c$-axis. (c) A side-view of two looped chains (A and B) of $\mathbf{2}$ perpendicular to the $a$-axis. two more pyridyl nitrogen atoms resulting an infinite structure. The size of the loop is measured by the diagonal lengths of rhombohedral squares $(21.587 \AA$ for $\mathrm{Co} \cdots \mathrm{Co}$, 13.522 $\AA$ for $\mathrm{O}{ }^{\cdots} \mathrm{O}$ ). The loop is filled with two $\mathrm{PF}_{6}{ }^{-}$ions and one water molecule. The water molecules are crystallographically disordered over four sites with occupancies of 0.25 . In packing structures, the looped chains are interacting with the --ABAB-- type stacking arrangement along c-axis by the hydrogen bonds between the carbonyl and amide groups from each chain (Figure 2b) in comparison with parallel stacking in zinc and cadmium compounds in the literature. ${ }^{30}$ The interlayer distance is $4.95 \AA$, equal to the half of the length of $c$-axis (Figure 2c). Surprisingly, the $\mathrm{PF}_{6}{ }^{-}$ ions and water molecules belong to 'looped chain $\mathrm{A}^{\text {' }}$ generate a cluster-form by hydrogen bonds $(\mathrm{F}---\mathrm{O} 2 \mathrm{~W})$ and this interacts not with 'looped chain A' but with a couple of neighboring 'looped chain B' through the H-bonds (O1W $\cdots$ $\mathrm{O} 2 \mathrm{~W}$ ) between coordinating water and non-coordinating water molecules.

The crystal structure of $\mathbf{3}$ is shown in Figure 3. It exhibits one-dimensional framework in which two adjacent $\mathrm{Zn}$ (II) ions are bridged by two $\mathbf{L}^{2}$ units, forming a looped chain extending along the crystallographic a-axis. Each $\mathrm{Zn}$ (II) ion

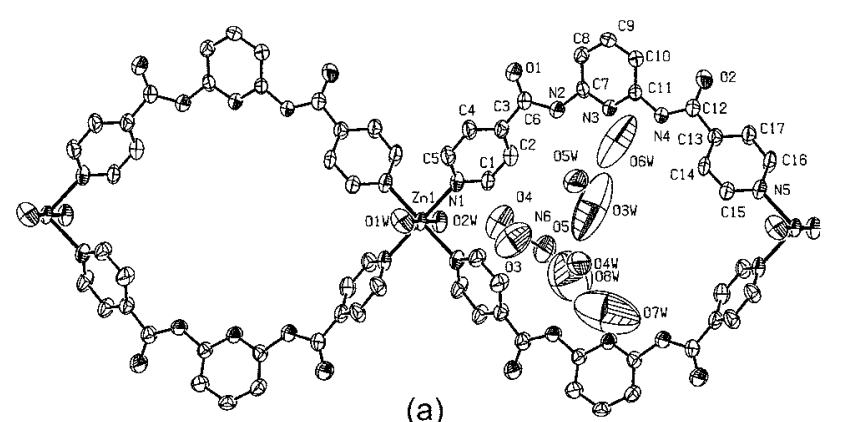

(a)

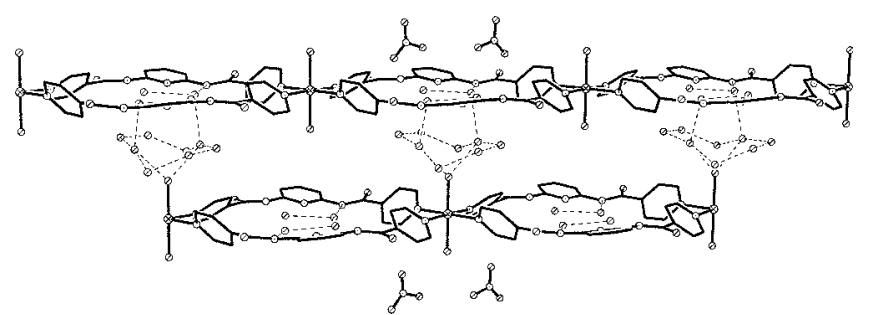

(b)

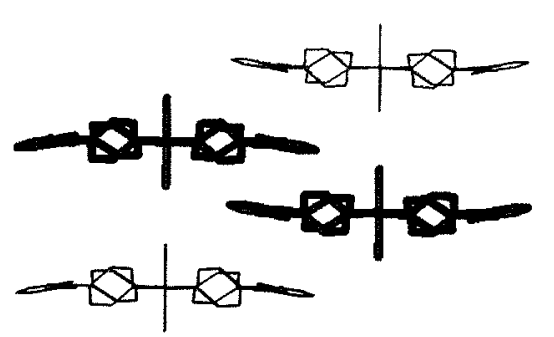

(c)

Figure 3. (a) ORTEP drawing of $\mathbf{3}$ with numbering scheme. Hydrogen atoms are omitted for clarity. (b) A view of two looped chains (A and B) of $\mathbf{3}$ perpendicular to the $a$-axis. (c) A view of four looped chains of $\mathbf{3}$ showing --ABCD-- packing down the $a$ axis. 
is coordinated by four pyridyl nitrogen atoms of four different $\mathbf{L}^{2}$ units in an equatorial plane, as well as two water molecules in trans-geometry. Two ligands and one $\mathrm{Zn}$ atom consist of a replicating structure unit. The size of the loop is measured by the diagonal lengths of rhombohedral squares $(15.785 \AA$ for $\mathrm{Zn} \cdots \mathrm{Zn}, 9.240 \AA$ for $\mathrm{N} \cdots \mathrm{N})$. The looped chains are packed in the --ABCD-- type (Figure 3c). Four water molecules occupy in the each cavity of the loop and form hydrogen bonds with amide nitrogens. The $\mathrm{NO}_{3}{ }^{-}$ions, 8 water molecules are located outside of the cavity and in space between loops, which form interlayer hydrogen bonds. There is no direct hydrogen bond between loops like 2 shown in Figure 2.

In conclusion, cyclic dimer and 1-D looped coordination polymers with trapped guest molecules or anions are described based on the dipyridyl ligands. These compounds have loops with rhombohedral structure as expected from the structure of the ligands. Hydrogen bonding plays an important role in the structures of these compounds. Further studies on new coordination polymers based on these ligands are in progress.

\section{Experimental Section}

General. The isonicotinic acid, 2,6-diaminopyridine and 4,4'-diaminodiphenyl ether were purchased from Aldrich and used as received. ${ }^{1} \mathrm{H}$ and ${ }^{13} \mathrm{C}\left\{{ }^{1} \mathrm{H}\right\}$ NMR spectra were recorded on Bruker DRX-500 and AVANCE 300 spectrometers at the Central Laboratory, Gyeongsang National University. Infrared and HRMS (EI) spectra were measured with a Mattson Genesis Series FT-IR spectrophotometer and a JEOL JMS-700 spectrometer, respectively, at the Central Laboratory, Gyeongsang National University. Microanalyses were performed by Elemental Analysen Systeme Vario EL in KBSI (Daegu).

$N, N^{\prime}$-Bis(4-pyridylcarbonyl)-4,4'-diaminodiphenyl ether $\left(\mathbf{L}^{1}\right)$. The product $\mathbf{L}^{1}$ was prepared by the procedure as $\mathbf{L}^{2}$ at room temperature using chloroform and obtained as yellowish white powder (60\%). Mp. $273-276^{\circ} \mathrm{C}$ (dec). Anal. Calcd. for $\mathrm{C}_{24} \mathrm{H}_{18} \mathrm{~N}_{4} \mathrm{O}_{3}$ : C 70.23, H 4.76, N 13.65. Found: $\mathrm{C}$ 70.60, H 4.76, N 13.67\%. IR (KBr, cm $\left.{ }^{-1}\right): 3345 \mathrm{~m}, 3300 \mathrm{~m}$ $1648 \mathrm{~s}, 1603 \mathrm{w}, 1530 \mathrm{~s}, 1507 \mathrm{~s}, 1404 \mathrm{~m}, 1322 \mathrm{w}, 1278 \mathrm{~m}$, $1211 \mathrm{~m}, 840 \mathrm{~m} .{ }^{1} \mathrm{H}$ NMR $\left(500 \mathrm{MHz}, \mathrm{DMSO}_{-} \mathrm{d}_{6}\right): \delta 10.53(\mathrm{~s}$, 2H, NHCO), 7.04-8.81 (m, 16H, Ar). ${ }^{13} \mathrm{C}$ NMR $(125.7 \mathrm{MHz}$, DMSO-d 6 ): $\delta 163.72,153.14,150.18,141.94,134.11$, 122.20, 121.55, 118.71. HRMS (m/z) Calcd. for $\mathrm{C}_{24} \mathrm{H}_{18} \mathrm{~N}_{4} \mathrm{O}_{3}$ : 410.1379. Found: $410.1382\left(\mathrm{M}^{+}\right)$.

$N, N^{\prime}$-Bis(4-pyridylcarbonyl)-2,6-diaminopyridine $\left(\mathrm{L}^{2}\right)$. Thionyl chloride $(11.89 \mathrm{~g}, 100 \mathrm{mmol})$ was added dropwise to isonicotinic acid $(12.31 \mathrm{~g}, 100 \mathrm{mmol})$ and triethylamine $(10.11 \mathrm{~g}, 100 \mathrm{mmol})$ in chloroform. The mixture was refluxed for $2 \mathrm{~h}$ and cooled down to room temperature. Then an acetonitrile solution of diaminopyridine $(5.45 \mathrm{~g}, 50 \mathrm{mmol}$ and triethylamine $(10.11 \mathrm{~g}, 100 \mathrm{mmol})$ were added dropwise to the resulting isonicotinyl chloride solution, cooled by salt and ice water. The solution was stirred for $12 \mathrm{~h}$, and then water was added. From the resulting solution, yellow powder was filtered and washed with a dilute $\mathrm{Na}_{2} \mathrm{CO}_{3}$ solution, distilled water, and then a small amount of cold methanol. The product $\mathbf{L}^{2}$ was obtained as yellowish white powder $(8.88 \mathrm{~g}, 55.8 \%) .{ }^{1} \mathrm{H}$ NMR $\left(300 \mathrm{MHz}, \mathrm{DMSO}_{-} \mathrm{d}_{6}\right): \delta$ 10.93 (s, $2 \mathrm{H} \mathrm{NHCO}$ ), $\delta 8.78$ (dd, $4 \mathrm{H} \mathrm{NCH}$ ), $\delta 7.89$ (dd, $4 \mathrm{H}$ $\mathrm{CCH}), \delta 7.9(\mathrm{~m}, 3 \mathrm{H} \mathrm{CHCHCHC}) .{ }^{13} \mathrm{C}$ NMR $(75.4 \mathrm{MHz}$, DMSO-d $\mathrm{d}_{6}$ ): $\delta$ 165.5, $150.8,150.3,141.5 \quad 122.3112 .5$. HRMS $(\mathrm{m} / z)$ Calcd. for $\mathrm{C}_{17} \mathrm{H}_{13} \mathrm{~N}_{5} \mathrm{O}_{2}$ : 319.1069. Found: $319.1086\left(\mathrm{M}^{+}\right)$.

$\left[\mathrm{Co}_{2} \mathrm{~L}^{1}{ }_{2}\left(\mathrm{NO}_{3}\right)_{2}\left(\mathrm{H}_{2} \mathrm{O}\right)_{4}\left(\mathrm{CH}_{3} \mathrm{OH}\right)_{2}\right] \cdot 2 \mathrm{NO}_{3} \cdot \mathrm{CH}_{3} \mathrm{CH}_{2} \mathrm{OCH}_{2}$ $\mathrm{CH}_{3}$ (1). Cobalt nitrate hexahydrate $(0.01 \mathrm{~g}, 0.034 \mathrm{mmol})$ was dissolved in methanol. L' $(0.014 \mathrm{~g}, 0.034 \mathrm{mmol})$ was dissolved in chloroform/methanol $(1: 1)$. These solutions were mixed together. Ether was then diffused into the resulting solution. Crystals suitable for an $\mathrm{X}$-ray structure determination were obtained. IR $\left(\mathrm{KBr}, v, \mathrm{~cm}^{-1}\right): 3283 \mathrm{~m}$, 1654 s, 1603 w, 1540 m, 1499 s, 1280 m, 1212 s, 831 w, 743 $\mathrm{w}, 685 \mathrm{w}$.

$\left\{\left[\mathrm{CoL}_{2}{ }_{2}\left(\mathrm{H}_{2} \mathrm{O}\right)_{2}\right] \cdot 2 \mathbf{P F}_{6} \cdot \mathrm{H}_{2} \mathrm{O}\right\}_{n}$ (2). Cobalt nitrate hexahydrate $(0.0071 \mathrm{~g}, 0.024 \mathrm{mmol})$ and $\mathrm{NH}_{4} \mathrm{PF}_{6}(0.01 \mathrm{~g}, 0.0061$ mmol) were dissolved in $3 \mathrm{~mL}$ methanol. $\mathbf{L}^{\prime}(0.0099 \mathrm{~g}$, $0.024 \mathrm{mmol}$ ) was dissolved in $4 \mathrm{~mL}$ chloroform/methanol $(1: 1)$. These solutions were mixed together. Ether was then diffused into the resulting solution. Crystals suitable for an $\mathrm{X}$-ray structure determination were obtained. The crystals were filtered and washed with chloroform/ether/methanol solution $(1: 1: 1)(0.015 \mathrm{~g}, 30 \%)$. IR $\left(\mathrm{KBr}, v, \mathrm{~cm}^{-1}\right): 3400$ m, $3245 \mathrm{~m}, 1659 \mathrm{~s}, 1600 \mathrm{~m}, 1539 \mathrm{~s}, 1500 \mathrm{~s}, 1408 \mathrm{~m}, 1387 \mathrm{~s}$, $1321 \mathrm{~m}, 1260 \mathrm{~m}, 1225 \mathrm{~s}, 1160 \mathrm{w}, 1103 \mathrm{w}, 1060 \mathrm{w}, 1013 \mathrm{w}$, $835 \mathrm{~s}, 690 \mathrm{~m}$. FAB mass spectrum: $\mathrm{m} / z=469\left[\mathrm{Co}^{1} \mathbf{L}^{+}\right]^{+}$, $604.4\left[\mathrm{Co}_{3} \mathbf{L}^{1}{ }_{4}-3 \mathrm{H}^{+}\right]^{3+}$, Mp $192{ }^{\circ} \mathrm{C}(\mathrm{dec})$. $\left\{\left[\mathrm{CoL}^{\mathbf{1}}\left(\mathrm{PF}_{6}\right)_{2}\right]-\right.$ $\left.\left(\mathrm{H}_{2} \mathrm{O}\right)\right\}_{\mathrm{n}}$ Anal. Calcd for $\mathrm{C}_{48} \mathrm{H}_{42} \mathrm{CoF}_{12} \mathrm{~N}_{8} \mathrm{O}_{9} \mathrm{P}_{2}: \mathrm{C}, 47.11 ; \mathrm{H}$, 3.46, N, 9.16. Found: C, 46.81; H, 3.68; N, 10.05\%.

$\left\{\left[\mathrm{ZnL}^{2}{ }_{2}\left(\mathrm{H}_{2} \mathrm{O}\right)_{2}\right] \cdot \mathbf{2} \mathrm{NO}_{3} \cdot \mathbf{1 2 H}_{2} \mathrm{O}\right\}_{\mathrm{n}}(\mathbf{3}) . \mathbf{3}$ was prepared by the same procedure as $\mathbf{1}$ using zinc(II) nitrate hexahydrate and $\mathbf{L}^{2}$ (30\%). IR. $3300 \mathrm{~m}, 1700 \mathrm{~s}, 1600 \mathrm{~s}, 1540 \mathrm{~s}, 1446 \mathrm{~s}$, $1300 \mathrm{~s}, 1080 \mathrm{w}, 860 \mathrm{w}, 802 \mathrm{~m}, 760 \mathrm{w}, 700 \mathrm{~m}, 589 \mathrm{w}$.

$\mathrm{X}$-ray structure determinations. All data were collected on a Bruker SMART diffractometer equipped with a graphite monochromated $\operatorname{Mo} K_{\alpha}(\lambda=0.71073 \AA)$ radiation source and a CCD detector; 45 frames of two-dimensional diffraction images were collected and processed to obtain the cell parameters and orientation matrix. ${ }^{21}$ The twodimensional diffraction images were collected, each of which was measured for $30 \mathrm{~s}$. The frame data were processed to give structure factors using the program SAINT. ${ }^{21}$ The absorption corrections were based on multiple and symmetry-equivalent reflections in the data sets using SADABS program. ${ }^{22}$ The structure was solved by a direct method and refined by full matrix least squares against $F^{2}$, for all data using SHELXTL software. ${ }^{23}$ All non-H atoms were refined with anisotropic displacement parameters. A summary of the crystallographic data is given in Table 1.

Supplementary materials. CCDC 255339, 255340, and 255341 contain the supplementary crystallographic data for $\mathbf{1 , 2}$, and $\mathbf{3}$, respectively. These data can be obtained free of 
Table 1. Crystallographic data and structure refinement parameters for all compounds

\begin{tabular}{|c|c|c|c|}
\hline Compound & 1 & 2 & 3 \\
\hline Empirical formula & $\mathrm{C}_{54} \mathrm{H}_{62} \mathrm{Co}_{2} \mathrm{~N}_{12} \mathrm{O}_{25}$ & $\mathrm{C}_{48} \mathrm{H}_{42} \mathrm{CoF}_{12} \mathrm{~N}_{8} \mathrm{O}_{9} \mathrm{P}_{2}$ & $\mathrm{C}_{36} \mathrm{H}_{54} \mathrm{~N}_{12} \mathrm{O}_{22} \mathrm{Zn}$ \\
\hline Formula weight & 1397.02 & 1223.77 & 1080.26 \\
\hline Temperature $(\mathrm{K})$ & $298(2)$ & $298(2)$ & $298(2)$ \\
\hline Crystal system & Monoclinic & Orthorhombic & Monoclinic \\
\hline Space group & $P 2{ }_{1} / c$ & Ccca & $C 2 / c$ \\
\hline$a(\AA)$ & $7.718(2)$ & $21.587(2)$ & $15.784(2)$ \\
\hline$b(\AA)$ & $15.0595(5)$ & $24.225(3)$ & $14.348(2)$ \\
\hline$c(\AA)$ & $26.641(9)$ & $9.8905(12)$ & $20.907(3)$ \\
\hline$\alpha\left(^{\circ}\right)$ & 90 & 90 & 90 \\
\hline$\beta\left(^{\circ}\right)$ & $90.736(7)$ & 90 & $90.708(3)$ \\
\hline$\gamma\left({ }^{\circ}\right)$ & 90 & 90 & 90 \\
\hline$V\left(\AA^{3}\right)$ & $3103.6(17)$ & $5172.3(10)$ & $4734.4(11)$ \\
\hline$Z$ & 2 & 4 & 4 \\
\hline$D_{\text {calc }}\left(\mathrm{g} \mathrm{cm}^{-3}\right)$ & 1.495 & 1.572 & 1.516 \\
\hline Absorption coefficient $\left(\mathrm{mm}^{-1}\right)$ & 0.627 & 0.501 & 0.617 \\
\hline$F(000)$ & 1448 & 2492 & 2256 \\
\hline Crystal size (mm) & $0.40 \times 0.20 \times 0.02$ & $0.40 \times 0.20 \times 0.20$ & $0.40 \times 0.20 \times 0.20$ \\
\hline$\theta$ Range $\left({ }^{\circ}\right)$ & 1.53 to 28.70 & 1.68 to 23.32 & 1.92 to $28.28^{\circ}$ \\
\hline Reflections collected & 19970 & 10953 & 14696 \\
\hline Independent reflections & $7573[\mathrm{R}(\mathrm{int})=0.2021]$ & $1874[\mathrm{R}(\mathrm{int})=0.0649]$ & $5507[\mathrm{R}(\mathrm{int})=0.0992]$ \\
\hline Completeness to theta & $28.70^{\circ} 94.3 \%$ & $23.32^{\circ} 99.9 \%$ & $28.28^{\circ} 93.9 \%$ \\
\hline Absorption correction & SADABS & SADABS & SADABS \\
\hline Max/min transmission & 0.2936 and 0.2207 & 0.2758 and 0.2319 & 0.2868 and 0.2332 \\
\hline Data/restraints/parameters & $7573 / 0 / 411$ & 1874 / 0 / 190 & $5507 / 0 / 324$ \\
\hline Goodness-of-fit on $F^{2}$ & 0.940 & 1.106 & 1.012 \\
\hline Final $R$ indices $[I>2 \sigma(I)]$ & $R_{1}=0.0843^{a}, w R_{2}=0.1691^{b}$ & $R_{1}=0.0565^{a}, w R_{2}=0.1615^{b}$ & $R_{1}=0.0888^{a}, w R_{2}=0.2159^{b}$ \\
\hline$R$ indices (all data) & $R_{1}=0.2844^{a}, w R_{2}=0.2619^{b}$ & $R_{1}=0.0882^{a}, w R_{2}=0.1971^{b}$ & $R_{1}=0.2255^{a}, w R_{2}=0.2823^{b}$ \\
\hline
\end{tabular}

${ }^{a} R_{1}=\Sigma\left\|F_{\mathrm{o}}|-| F_{\mathrm{c}}\right\| / \Sigma\left|F_{\mathrm{o}}\right| .{ }^{b} w R_{2}=\left[\Sigma\left[w\left(F_{\mathrm{o}}{ }^{2}-F_{\mathrm{c}}{ }^{2}\right)^{2}\right] / \Sigma w\left(F_{\mathrm{o}}{ }^{2}\right)^{2}\right]^{1 / 2}$.

charge via www.ccdc.cam.ac.uk/data_request/cif, by emailing data_request@ccdc.cam.ac.uk, or by contacting The Cambridge Crystallographic Data Centre, 12, Union Road, Cambridge CB2 1EZ, UK; fax: +44 1223336033.

Acknowledgement. The support of the Korea Research Foundation (KRF 2002-002-C00047) is gratefully acknowledged.

\section{References}

1. Seo, J. S.; Whang, D.; Lee, H.; Jun, S. I.; Oh, J.; Jeon, Y. J.; Kim, K. Nature 2000, 404, 982.

2. Kondo, M.; Yoshitomi, T.; Seki, K.; Matsuzaka, H.; Kitagawa, S. Angew. Chem. Int. Ed. Engl. 1997, 36, 1725.

3. Jung, O.-S.; Kim, Y. J.; Lee, Y.-A; Park, J. K.; Chae, H. K. J. Am. Chem. Soc. 2000, 122, 9921.

4. Hou, H.; Song, Y.; Xu, H.; Wei, Y.; Fan, Y.; Zhu, Y.; Li, L.; Du, C. Macromolecules 2003, 36, 999.

5. Gao, E.-Q.; Bai, S.-Q.; Wang, Z.-M.; Yan, C.-H. Dalton Trans. 2003, 1759 .

6. Kim, Y. J.; Lee, Y.-A; Park, K.-M.; Chae, H. K.; Jung, O.-S. Bull. Korean Chem. Soc. 2002, 23, 1106.

7. Lee, Y.-A; Kim, S. A.; Jung, S. M.; Jung, O.-S.; Oh, Y. H. Bull. Korean Chem. Soc. 2004, 25, 581.

8. Kim, S. A.; Lee, Y.-A; Park, K.-M.; Shim, Y.-B.; Jung, O.-S. Bull. Korean Chem. Soc. 2004, 25, 1564.

9. Barnett, S. A.; Champness, N. R. Coord. Chem. Rev. 2003, 246,
145.

10. Yaghi, O. M.; Li, H. J. Am. Chem. Soc. 1995, 117, 10401.

11. Losier, P.; Zaworotko, M. J. Angew. Chem. Int. Ed. Engl. 1996, $35,2779$.

12. Hennigar, T. L.; MacQuarrie, D. C.; Losier, P.; Rogers, R. D.; Zaworotko, M. J. Angew. Chem. Int. Ed. Engl. 1997, 36, 972.

13. Hartshorn, C. M.; Steel, P. J. J. Chem. Soc., Dalton Trans. 1998 3927.

14. Shin, D. M.; Lee, I. S.; Jung, Y. K.; Lah, M. S. Inorg. Chem. 2003, 42,5459 .

15. Seo, J.; Moon, S.-T.; Kim, J.; Lee, S. S.; Park, K.-M. Bull. Korean Chem. Soc. 2003, 24, 1393.

16. Beatty, A. M. Coord. Chem. Rev. 2003, 246, 131.

17. Muthu, S.; Yip, J. H. K.; Vittal, J. J. J. Chem. Soc., Dalton Trans. 2001, 3577.

18. Uemura, K.; Kitagawa, S.; Kondo, M.; Fukui, K.; Kitamura, R.; Chang, H.-C.; Mizutani, T. Chem. Eur. J. 2002, 8, 3587.

19. Li, Y.-X.; Li, Y.-H.; Zeng, X.-R.; Xiong, R.-G.; You, X.-Z.; Fun, H.-K. Inorg. Chem. Commun. 2003, 6, 1144.

20. Shin, Y. W.; Kim, T. H.; Lee, K. Y.; Park, K.-M.; Lee, S. S.; Kim, J. Inorg. Chem. Commun. 2004, 7, 374.

21. Siemens: Area Detector Control and Integration Software, Version 5.0. in SMART and SAINT; Siemens Analytical X-ray Instruments Inc.: Madison, Wisconsin, 1997.

22. Sheldrick, G. M. SADABS: Program for Scaling and Correction of Area Decetor Data; University of Göttingen: Göttingen, Germany, 1997.

23. Siemens: Structure Determination Programs, Version 5.03 in SHELXTL; Siemens Analytical X-ray Instruments Inc.: Madison, Wisconsin, 1997. 